\title{
PERFORMANCE EVALUATION OF LOCALLY FABRICATED MECHANICAL SURFACE AERATOR
}

${ }^{*}$ Anfal E. Khalaf ${ }^{1}$

1) Environmental Engineering Department, College of Engineering, Mustansiriyah University , Baghdad, Iraq

\author{
Mohammed A. Rashid ${ }^{1}$
}

\begin{abstract}
Experimental analysis for a fabricated LowSpeed surface aerator that can be used in wastewater and water treatment is presented in this research. The designed impeller configuration was tested to determine its power consumption, standard oxygen transfer rate (SOTR), and standard aeration efficiency (SAE). Impeller oxygen transfer and power consumption in a scaled laboratory tank were measured during aeration phase. The impeller was consisting of 8 inclines flat blades with an angle of $45^{\circ}$ from center of the disc, was operated at 3 different immersion depths and 5 different rotational speeds for examining the impact of such factors on impeller efficiency. The results recorded that the best standard aeration efficiency for this configuration is $\left(0.206 \mathrm{Kg} . \mathrm{O}_{2} / \mathrm{KW} . \mathrm{hr}\right)$ at $120 \mathrm{rpm}$ and $7 \mathrm{~cm}$ depth of the submersion, i.e. submersion depth to impeller diameter (h/D) ratio equals 0.175 . Submergence depth increase beyond this limit would result in SAE decrease and definitely result into more power consumption.
\end{abstract}

Keywords: Surface aerators, Oxygen transfer, Power consumption, Standard aeration efficiency.

\section{Introduction}

Aeration is one of the important processes conducted in wastewater and water treatment.

This process' primary goal is transferring oxygen from atmosphere to water. Because of a low oxygen transfer rate and poor solubility of oxygen, enough oxygen to supply the aerobic waste demands doesn't enter through the natural air-water interface, making such process an important aspect of treatment. The aeration approach is utilized for adding more interfaces as well as boosting oxygen transfer rates such that dissolved oxygen rises to a particular level, allowing aerobic bacteria for removing the effluent's biochemical oxygen need. A variety of aeration systems were developed and implemented. The selection of the appropriate system affected by several factors including the purpose to be performed, the tank geometry and shape, the system installation, and operation cost (Metcalf and Eddy [1]). The aeration systems divided into five major groups as listed below:

(a) Diffused Aeration, (b) Mechanical and Submerged Agitator Aeration (c) Cascade Aeration, (d) Pure Oxygen Aeration, (e) Surface Aeration.

Surface aerators have been commonly used due to their ease of operation and comparable efficiency.

To design surface aerator with high efficiency, it needs to diagnose the factors which are related to the phenomena of transfer of oxygen and to find out the best method to maximize the efficiency of aeration rate. This necessitates an increase in the overall oxygen transfer coefficient (KLa) while lowering power usage.

*Corresponding Author: anfalkhalaf41@gmail.com 
Several researches have studied surface aerators and the effect of impeller shape and the shape of the water tank on the aeration process.

Khare (1999) [2], Amanullah (1998) [3], Cooke (2005) [4], Chen (1999) [5], Saito (1992) [6]: found out that the power consumption for impellers with curved blades has been less compared to that consumed via general Rushton impeller.

Cancino et al. (2004) [7] [8]: provided theoretical design that has been related to rotor throughout the use of standard equations of mass transfer as well as mechanical method utilizing the superficial similarities of the aerators to the axial-flow pumps. Totally 23 different types of rotor configurations have been utilized and tested (experimentally). The efficiency of the oxygenation at $10^{\circ} \mathrm{C} 1.769 \mathrm{~kg}$ $\mathrm{O}_{2} / \mathrm{kWh}$ (Standard oxygenation efficiency = $1.805 \mathrm{~kg} \mathrm{O} / \mathrm{kWh}$ ) for "Kinetic 3" propeller, which had a $94 \mathrm{~mm}$ diameter, angle of the inlet $11^{\circ}$, and the exit angle of $25^{\circ}$. The Conrad propeller which had $104 \mathrm{~mm}$ diameter, the angle of the inlet of $25^{\circ}$, and the angle of exit $12^{\circ}$, recorded the maximum value for global mass transfer coefficient at $10 \mathrm{C} 3.249 \mathrm{~h}^{-1}$

S.B. Thakre, L.B. Bhuyar, S.J. Deshmukh (2008)[9]: studied the differences in aeration efficiency (AE) and oxygen transfer coefficient $\left(\mathrm{K}_{\mathrm{L}} \mathrm{a}\right)$ for various configuration types of aerators by changing parameters, (i.e.), Aerator speed, depth of the immersion, and blade tip angle to achieve the highest values of $\mathrm{AE}$ and $\mathrm{K}_{\mathrm{L}} \mathrm{a}$. $\mathrm{A}$ total of 6 aerator configurations have been created and experimentally tested for the parameters mentioned earlier. The curved blade rotor $(\mathrm{CBR})$ is one of the potential aerators with a $47^{\circ}$ blade tip angle. Also, the mathematical formulas have been utilized to predict the performance of CBR in terms of $\mathrm{K}_{\mathrm{L}} \mathrm{a}$ and power consumption. The laboratory-scale studies show the results of optimum value of $\mathrm{AE}$ and $\mathrm{K}_{\mathrm{La}}$ were $2.269 \mathrm{~kg} \mathrm{O} 2 / \mathrm{kWh}$ and $10.33 \mathrm{~h}^{-1}$

L.B. Bhuyar1, S.B. Thakre1*, N.W. Ingole (2009)[10]: The purpose of the present study is designing curved blade surface aerator with higher effectiveness that could be used in treating domestic and municipal domestic wastewater in an oxidation ditch. The experiments have been conducted in an oxidation ditch to evaluate design properties of a curved blade mechanical surface aerator. Also, the design employed in this work has been used for oxidation ditch mechanisms, and rotation speed has been between 36 and $60 \mathrm{rpm}$. In addition, the optimal $\mathrm{AE}$ has been found to be $2.269 \mathrm{kgO} 2 / \mathrm{kWh}$ at $48 \mathrm{rpm}, 5.5 \mathrm{~cm}$ immersion depth, and $47^{\circ}$ blade tip angle, whereas the standard aeration efficiency was found to be $2.95 \mathrm{kgO} 2 / \mathrm{kWh}$ for the curved blade aerator.

Devi et al. (2011) [11]: an arrowhead impeller used during the process for experimentally examining the impact of impeller submergence depths on the consumption of power. The results showed the optimum submergence depth was found to be between (0.8-0.9) times impeller diameter.

Molnar et al. (2014) [12]: Investigated the efficiency of mixing for a stirred vessel experimentally and numerically, using various impeller configurations carrying a different number of blades (3, 4, 5, and 6) blades and speeds of rotating. It has been obtaining numerically and experimentally the mixing time, efficiency, and energy consumption for all four configurations.

A. Mohammad pour, et al (2015) [13]: examined the mixing time and efficiency in the aeration Tank. A laboratory-scale surface aeration impeller in an aerated vessel was designed to determine the standard aeration 
efficiency SAE and time of mixing throughout different operational parameters like the rotor speed rpm, immersion depth of impeller, and water level were used to analyze the SAE and mixing requirements . A Rushton turbine was used to aerate the surface. The results recorded the changes in the immersion depth of the impeller have a massive impact on SAE in comparison with the changes in impeller diameter. When the rotor speeds up (150-200) rpm the SAE increases and then decreases. In addition, the mixing time decreases as the rotor speed increases. In the area of this analysis, optimal values for rotor speed $169 \mathrm{rpm}$, for impeller immersion depth $25 \mathrm{~mm}$, and water level $30 \mathrm{~cm}$, have been recorded using Response surface methodology (RSM) statistical optimization to yield the highest value of SAE.

Jayraj P, Subha M. Roy, C. K. Mukherjee and B. C. Mal (2017) [14]: The research is on design characteristics of submersible aerator. Aeration tests were carried out on the original and the modified submersible aerator in order to evaluate its performance and to optimize the aeration efficiency. The propeller angular position $(\alpha)$ and propeller submergence depth (d) were diverse to study these parameters' influence on standard aeration efficiency (SAE). The aerator was modified to have a provision to change $\alpha$ and $d$ of the aerator. The efficiency percentage increases after adjustment were registered to be $92.50 \%$. At $\alpha=75^{\circ}$ and $d=350$ $\mathrm{mm}$, the optimized value of SAE is $0.616 \mathrm{~kg} \mathrm{O}_{2} /$ Kwh.

Mohamed R. Shaalan, Mohamed Adel a, Diaa S. El Monayeri and Radwan M. Kamal (2019)[15]: The article presented a comparative laboratory analysis of mechanical surface aerators with various configurations that could be utilized in wastewater and water treatment plants. The typical aeration efficiency and consumption of power for the impellers with curved blades that have a different number of blades (3, 6, 9, and 12) were compared in a laboratory-scale tank. Submergence depth and rotor speed. The results show the optimal configuration (nine blades) showed the best $\mathrm{AE}$ value $\left(2.60 \mathrm{Kg}\right.$. $\left.\mathrm{O}_{2} / \mathrm{KW} . \mathrm{hr}\right)$ at a rotating speed of $500 \mathrm{rpm}$. Furthermore, ratio of submersion depth $(\mathrm{h} / \mathrm{D}=0.350)$ has been found optimal, these factors leading to the maximum standard aeration efficiency, it was recorded that any raising of submergence depth ratio above that value will induce a decrease in standard aeration efficiency due to the eventual rise in input power usage in this situation.

The present work aimed to evaluate the behavior of locally fabricated surface mechanical aerator to get the optimum operating conditions.

\section{Material and Method:}

\subsection{Instruments and material:}

The Schematic diagram as can be seen in in Fig.1, consists of:

1. a galvanized tank locally fabricated with dimensions of $1.5 \mathrm{~m}^{*} 1.5 \mathrm{~m}^{*} 0.9 \mathrm{~m}$ the capacity of the tank is $2.025 \mathrm{~m}^{3}$ and equipped with a holder fabricated from an Iron I- shape section beam for the placement of the driving motor and gearbox and VFD. For water drainage, drain pipe with a valve has been installed at tank's bottom.

2. Mechanical surface aerator locally fabricated with dimension details as recorded in (Table 1) (Plate 1).

3. The dissolved oxygen probe serves as a sensor for both water temperature and dissolved oxygen.

4. Gearbox motor: manufactured via SEWEURODRIVE Company with input 
power 0.75Killo Watts, 3 Phase, $50 \mathrm{~Hz}$, $1435 \mathrm{rpm}$ with an efficiency $81 \%$.

5. POWTRAN Company's variable frequency drive (VFD) in order to manage aerator's speed, with a power of $1.5 \mathrm{KW}$ and a frequency of $50 \mathrm{~Hz}$.

6. Voltage and current meter for measuring the line current and voltage of the motor.

7. Dissolved oxygen Meter.

8. Drainpipe with a valve.

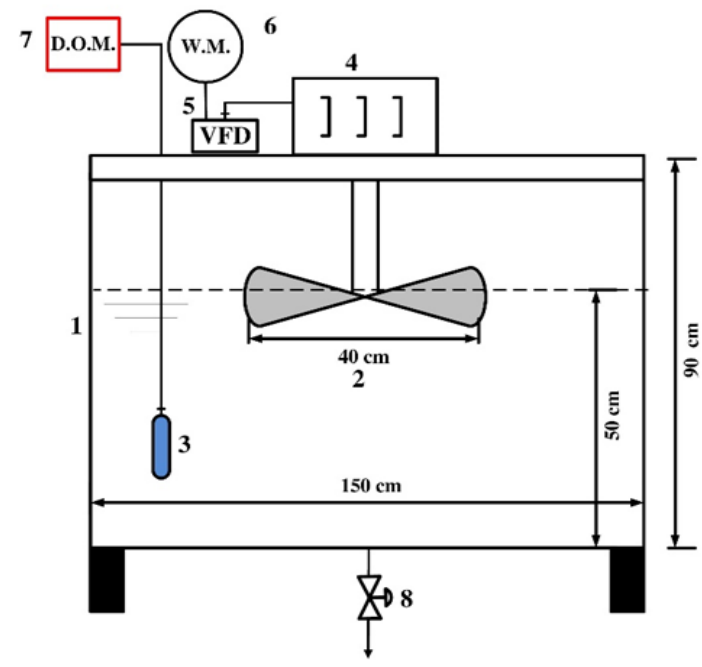

Figure.1 Diagram of experimental setup

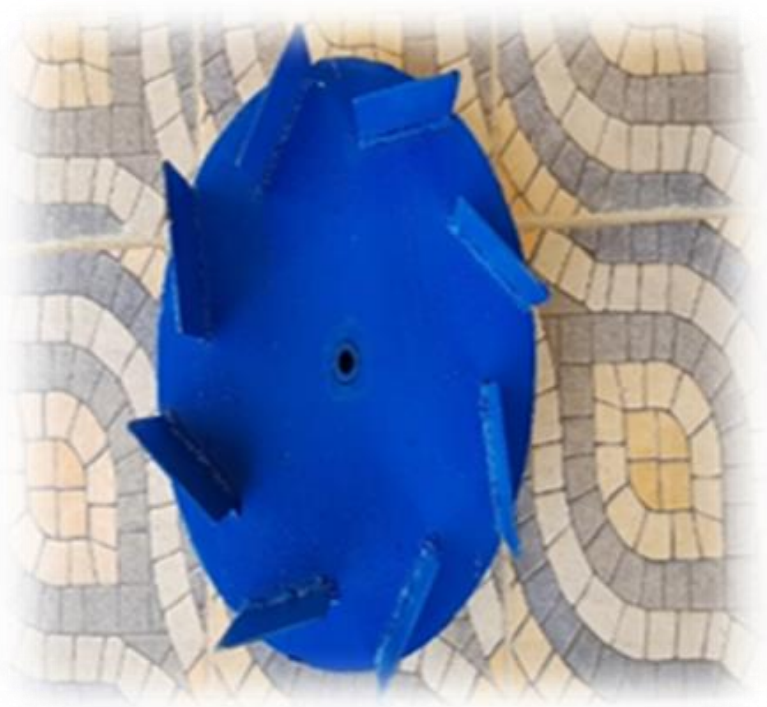

Plate 1. Eight Curved Blade Impeller
Table 1. Data of Testing Tank and the Blade Impeller

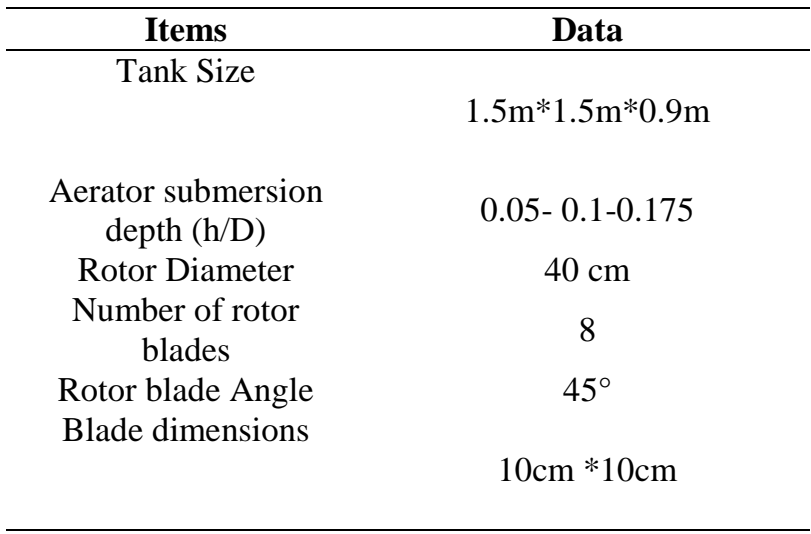

15 experimental work were conducted in locally designed system as shown in rig (Plate.2).

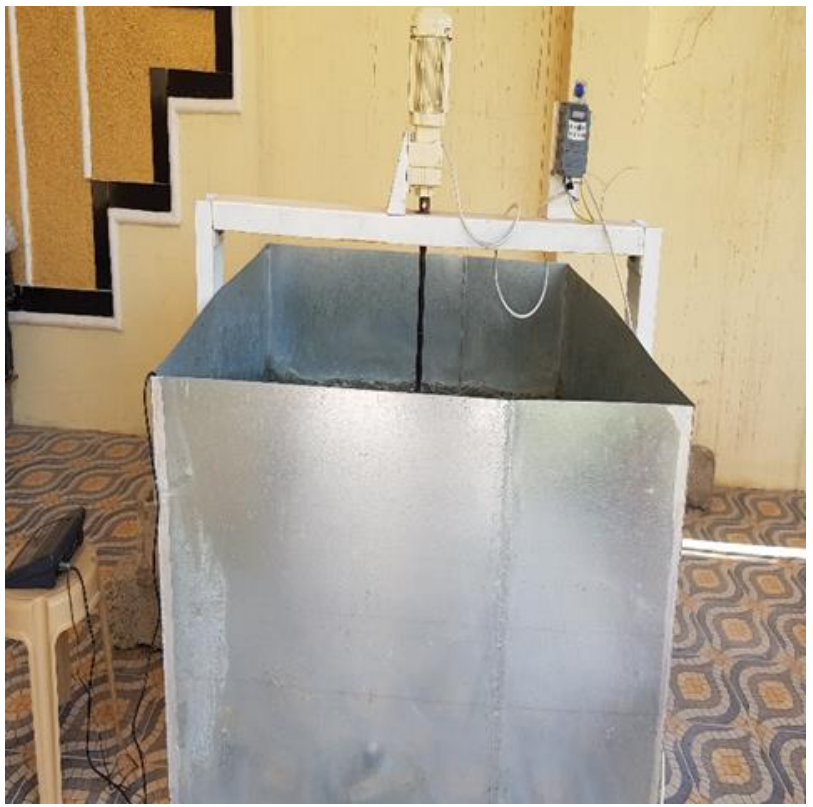

Plate 2. Shows the system rig

\subsection{The Methodology:}

The procedure of de- oxygenation-oxygenation the non-steady-state re-aeration test [16-21] was used in the present work. Deoxygenation has been carried out through adding $7.88 \mathrm{mg} / \mathrm{L}$ per $1 \mathrm{mg} / \mathrm{L}$ DO concentration. Also, cobalt chloride wasn't employed throughout the test since it is deemed dangerous to human health [7]. Sulfite additions were made in excess of what was theoretically needed of sodium sulfite. After 
that, in the case when the water is reoxygenated, a mechanical surface aerator is used to quantify the change in DO concentration. DO concentration levels have been recorded by a DO meter at scheduled intervals as they grow from approximately $0 \%$ saturation to minimum of $90 \%$ saturation.

\subsection{Oxygen Mass Transfer Coefficient $K_{\vec{l}} a$}

Based upon two-film theory, Eqs. (1) and (2), respectively, give the oxygen transfer rate and coefficient of the volumetric transfer of the oxygen at $\mathrm{T}\left({ }^{\circ} \mathrm{C}\right)[22]$ :

$\frac{d c}{d t}=K_{L} a_{T}\left(C_{s}-C_{T}\right)$

$K_{L} a_{T}=\frac{\ln \left(C_{S}-C_{o}\right)-\ln \left(C_{S}-C_{t}\right)}{t}$

$\mathrm{K}_{1} \mathrm{a}$ can also be calculated as the slope of a linear plot between $\ln \left(\mathrm{C}_{\mathrm{s}}-\mathrm{C}_{\mathrm{T}}\right)$ and the time t. $\mathrm{C}_{\mathrm{s}}$ can be calculated for various fluid temperature degrees using Eq3 [16,18] :

$C_{S T}=2234.34(T+45.9)^{-1.31403}$

To equate the coefficients at temperature degrees other than the standard temperature $\left(20^{\circ} \mathrm{C}\right)\left(\mathrm{K}_{\mathrm{L}} \mathrm{a}_{20}\right)$ provided through Vant-Hoff Arrhenius eq. (4):

$$
\left(\mathrm{k}_{\mathrm{l}} \mathrm{a}\right)_{20 \mathrm{C}}=\mathrm{K}_{\mathrm{l}} \mathrm{a}_{\mathrm{T}} \times 1.0240^{(20-\mathrm{T})}
$$

The SOTR can be calculated using the eq.4, which depends on the oxygen mass transfer coefficient:

SOTR $=K_{l} a_{20{ }^{\circ} \mathrm{C}} C_{s 20} \mathrm{~V}$

\subsection{Power Consumption}

The consumed power $(\mathrm{P})$ by the aerator can be calculated using eq.6 [23]:

Power delivered, watt $=$ (line voltage) (line amperage) (power factor) (Motor and gear efficiencies)

\subsection{Aeration efficiency}

The essential factor that is utilized for evaluating the surface aerator's performance is added oxygen per kilo watt. hr. (Standard efficiency of the aeration), the SAE may be obtained calculated through the following equation:

$S A E=S O T R / P$

During the course of tests run, the DO concentration, water temperature, and power consumption were recorded continuously, the results measured and plotted the SOTR, coefficient of oxygen mass transfer $\mathrm{K}_{\mathrm{La}}$, and SAE. All of those methods for calculating the mass transfer coefficient and efficiency based on the ASCE/EWRI 2006[20] standard.

\section{Results and Discussion:}

15 experiments were conducted with different submersion depth and speeds, dissolved oxygen concentrations (DO) and power consumption were measured and recorded at a fixed height of water of $50 \mathrm{~cm}$.

\subsection{Effect of Submersion Depth:}

Fig. 2 illustrated the DO concentration $(\mathrm{mg} / \mathrm{l})$ Versus time for impeller with 8 blades at different submergence depth ratio at $120 \mathrm{rpm}$, the conclusion was that $(\mathrm{h} / \mathrm{D}=0.175)$ represented optimum submergence depth in which the DO reaches almost saturation among the three submersion depths that have been tested.

Fig.3 illustrated the coefficient of the Oxygen mass transfer (Kla) vs. sub-mergence depth for a variety of the submersion depth ratios and it has been identified that the submergence depth ratio $(\mathrm{h} / \mathrm{D}=0.175)$ approximately the ratio of the optimal submergence depth. It has been indicated that the increase in submersion depth 
will result in an increase in the input power as can be seen in Fig. 4

Fig.5 shows the SAE versus sub-mergence depths ratio at $120 \mathrm{rpm}$. Also, the optimum submergence depth was $\mathrm{h} / \mathrm{D}=0.175$, any further increases in the depth of the submergence will result in an increase of power input and thus a reduction in SAE.

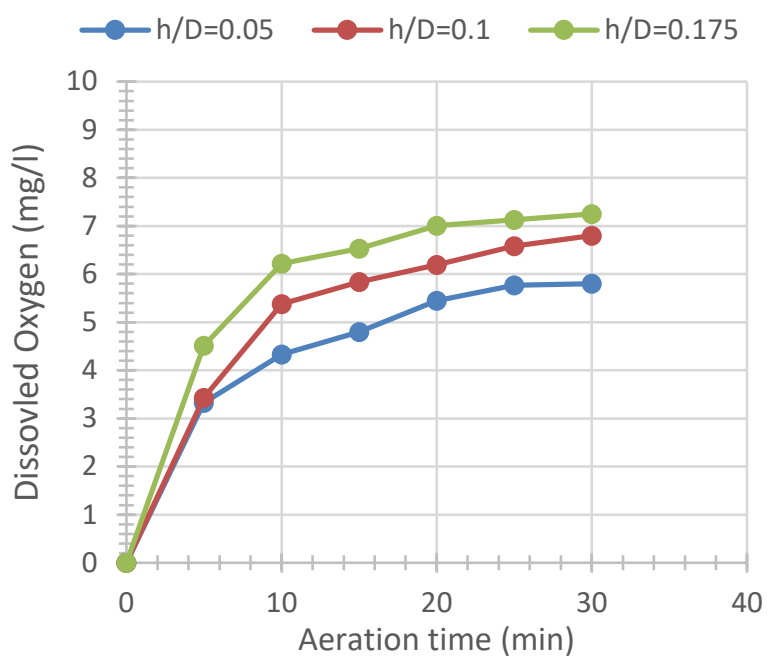

Figure 2. Shows the correlation between dissolved Oxygen concentrations $(\mathrm{mg} / \mathrm{l})$ and Time $(\mathrm{min})$ at various submersion depth ration at rotational speed $(\mathrm{N}=120 \mathrm{rpm})$

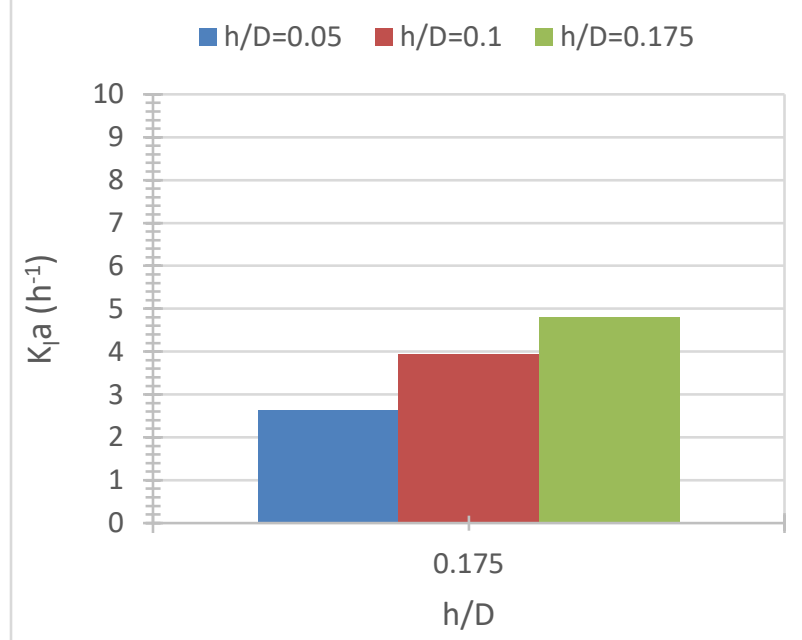

Figure 3. shows the correlation between oxygen mass transfer coefficients $\left(\mathrm{K}_{1} \mathrm{a}\right)$ and submersions depth ratio $(\mathrm{h} / \mathrm{D})$ at rotation speed $(\mathrm{N}=120 \mathrm{rpm})$.

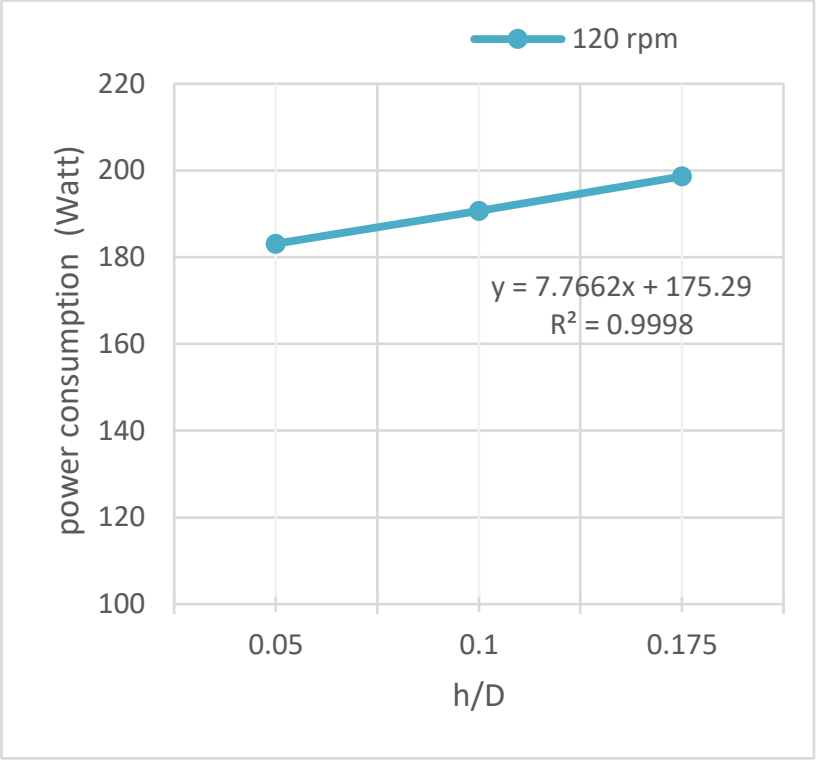

Figure 4. shows the correlation between the power consumption and the different submersion depths ratio at rotational speed $(\mathrm{N}=120 \mathrm{rpm}$.

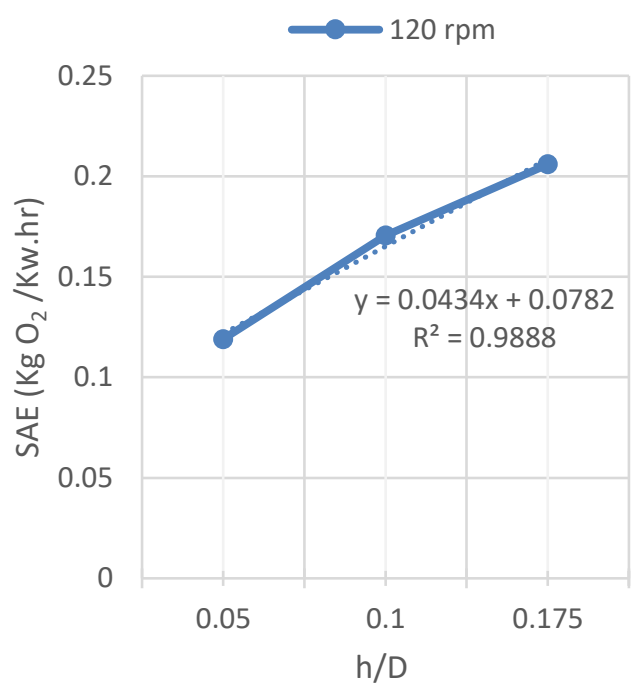

Figure 5. shows the correlation between $\mathrm{SAE}$ and the ratio of Submersion depth $(\mathrm{h} / \mathrm{D})$ for rotational speed ( $\mathrm{N}=120 \mathrm{rpm})$.

\subsection{Effect of Aeration time:}

The aeration time was ranged in this study between (0-30) $\mathrm{min}$, it has been indicated that the DO concentration in aeration tank increases with the time, however, it does not necessarily reach saturation because it depends also on 
other factors such as the speed of rotor, submersion depth and the impeller configuration.

Fig.6 \&7 illustrated the DO concentration versus time in varies submersion depth at 80 and $120 \mathrm{rpm}$.

Generally, the oxygen transfer rate, which is presented by the slop of the shown curve, decreases with time as dissolved oxygen in water increases.

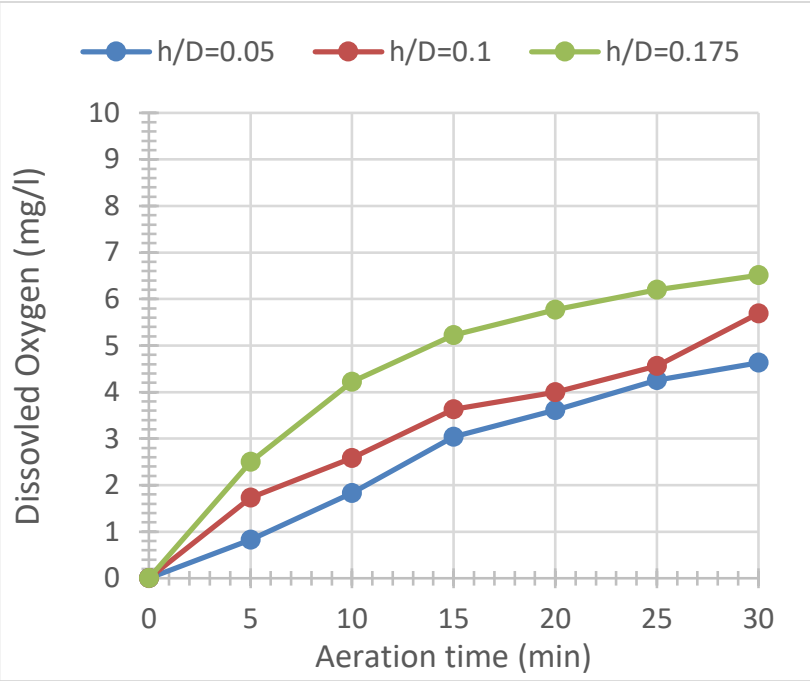

Figure 6. shows the dissolved oxygen concentration $(\mathrm{mg} / \mathrm{l})$ and Time $(\mathrm{min})$ at different submersion depth ratio (h/D) for rotational speed ( $\mathrm{N}=80 \mathrm{rpm})$.

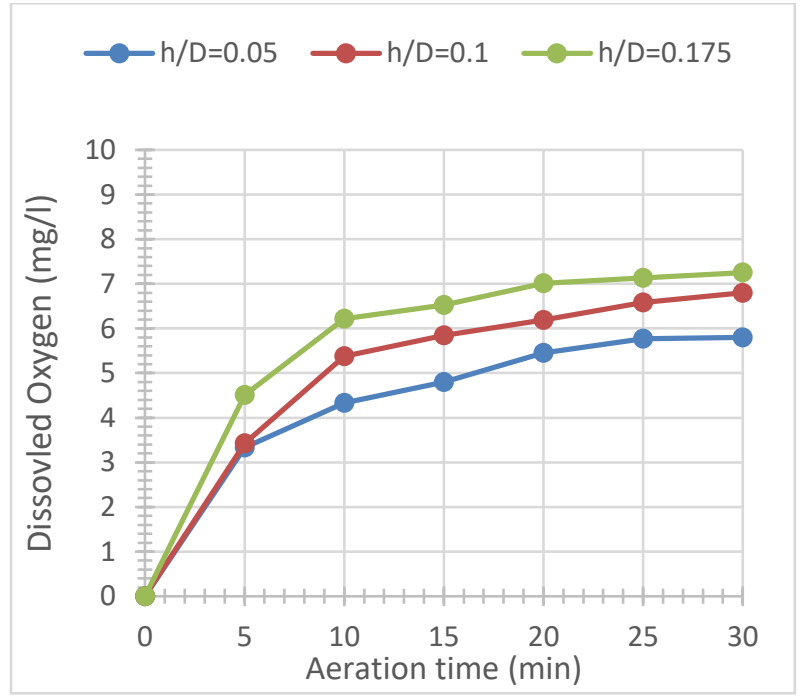

Figure 7. shows the dissolved oxygen concentration $(\mathrm{mg} / \mathrm{l})$ and time $(\mathrm{min})$ at different submersion depth ratio $(\mathrm{h} / \mathrm{D})$ for rotational speed $(\mathrm{N}=120 \mathrm{rpm})$.

\subsection{Effect of Aerator Speed:}

The rotational speed was ranged $(40$ - 120) rpm during this study. When the aerator speed rises above $80 \mathrm{rpm}$, the splashing will occurs in the tank. As seen in Fig. 8, rotational speed has a significant impact on DO. With the increase in rotation speed, the time that is needed for reaching the saturation decrease. As a result, as seen in Fig9. The oxygen mass transfer coefficient increases. Despite the increase in the consumption of the power, if the speed of the aerator is increased, the SAE will increase as well despite the increase of the consumption of the power, as can be seen in Figs.10 and 11.

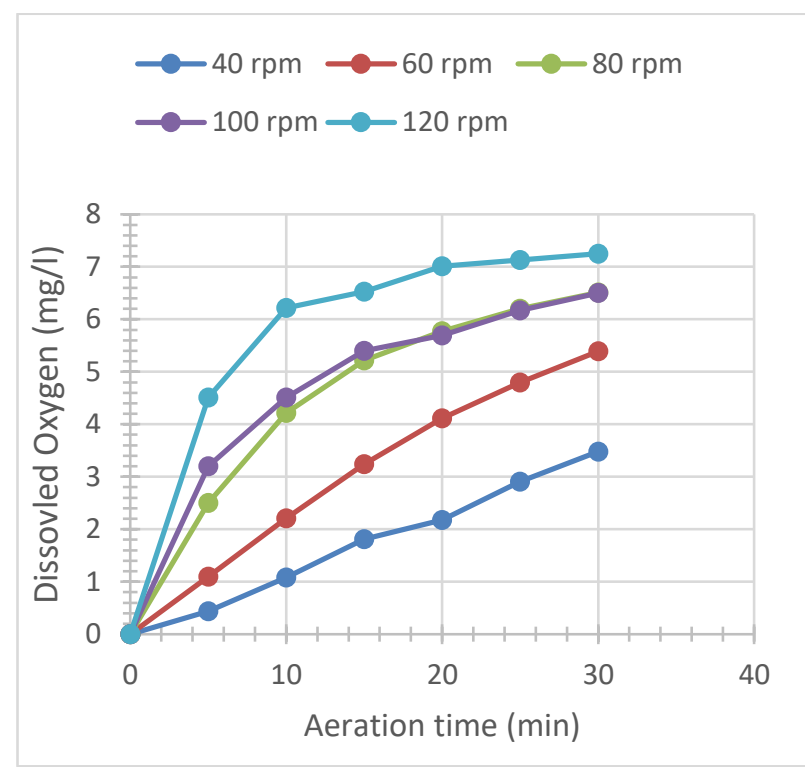

Figure 8. shows the corrolation between dissolved oxygen concentration $(\mathrm{mg} / \mathrm{l})$ and time $(\mathrm{min})$ at submersion depth ratio $(\mathrm{h} / \mathrm{D}=0.175)$ for different rotational speed. 


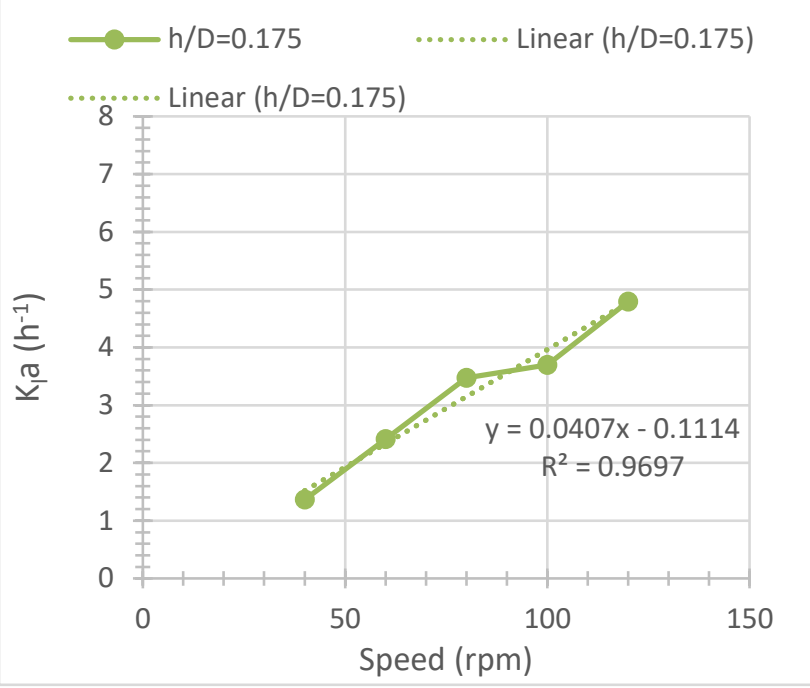

Figure 9. shows the correlation between oxygen mass transfer coefficients $\left(\mathrm{K}_{1} \mathrm{a}\right)$ and rotational speed $(\mathrm{rpm})$ at submersion depth ratio $(\mathrm{h} / \mathrm{D}=0.175)$.

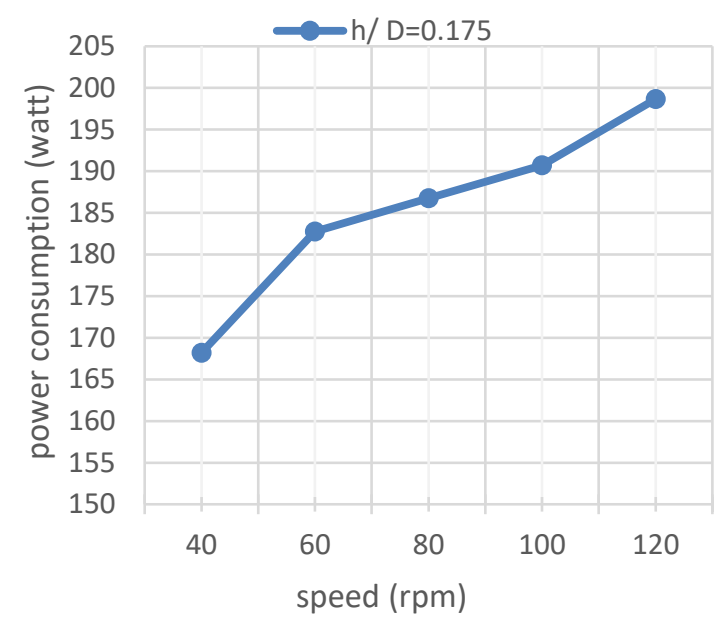

Figure 10. shows the correlation between Power consumption (watt) and rotational speed (rpm) for submersion depth ratio $(\mathrm{h} / \mathrm{D}=0.175)$.

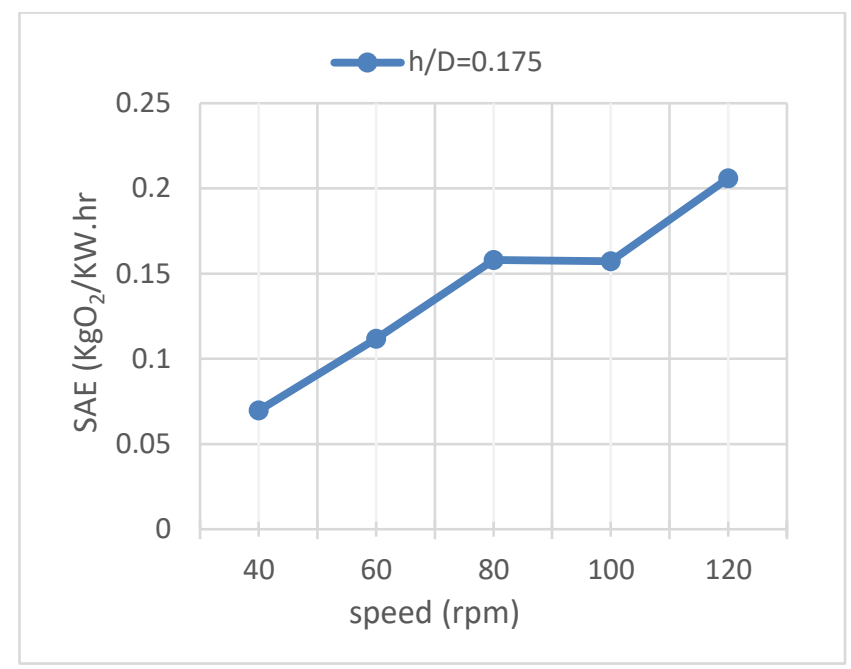

Figure 11. shows correlation between SAE and the rotational speed (rpm) for submersion depth ratio $(\mathrm{h} / \mathrm{D}=0.175)$.

Table 2, 3, and 4 shows the results calculated for the experimental work.

Table 2. shows results at submersion depth $\mathrm{ratio}(\mathrm{h} / \mathrm{D}=0.05)$

\begin{tabular}{llll}
\hline Speed (rpm) & $\mathrm{K}_{\mathrm{l}} \mathrm{a}\left(\mathrm{hr}^{-1}\right)$ & $\begin{array}{l}\text { Power } \\
\text { (watt) }\end{array}$ & $\begin{array}{l}\mathrm{SAE}(\mathrm{Kg} . \\
\left.\mathrm{O}_{2} / \mathrm{KW} . \mathrm{hr}\right)\end{array}$ \\
40 & 0.919 & 141.65 & 0.0529 \\
60 & 1.725 & 156.96 & 0.0923 \\
80 & 1.755 & 165.59 & 0.0877 \\
100 & 2.453 & 175.27 & 0.1197 \\
120 & 2.618 & 183.12 & 0.1190 \\
\hline
\end{tabular}

Table 3. shows results at submersion depth $\operatorname{ratio}(\mathrm{h} / \mathrm{D}=0.1)$

\begin{tabular}{llll}
\hline Speed (rpm) & $\mathrm{K}_{\mathrm{l}} \mathrm{a}\left(\mathrm{hr}^{-1}\right)$ & $\begin{array}{l}\text { Power } \\
\text { (watt) }\end{array}$ & $\begin{array}{l}\mathrm{SAE}(\mathrm{Kg} . \\
\left.\mathrm{O}_{2} / \mathrm{KW} . \mathrm{hr}\right)\end{array}$ \\
40 & 1.011 & 158.92 & 0.0522 \\
60 & 1.656 & 167.66 & 0.0792 \\
80 & 2.66 & 175.87 & 0.124 \\
100 & 4.218 & 184.08 & 0.191 \\
120 & 3.93 & 190.71 & 0.170 \\
\hline
\end{tabular}


Table 4. shows results at submersion depth ratio(h/D=0.175)

\begin{tabular}{llll}
\hline Speed (rpm) & $\mathrm{K}_{\mathrm{la}}\left(\mathrm{hr}^{-1}\right)$ & $\begin{array}{l}\text { Power } \\
\text { (watt) }\end{array}$ & $\begin{array}{l}\mathrm{SAE}(\mathrm{Kg} . \\
\left.\mathrm{O}_{2} / \mathrm{KW} . \mathrm{hr}\right)\end{array}$ \\
40 & 1.36 & 169.19 & 0.0695 \\
60 & 2.41 & 182.76 & 0.111 \\
80 & 3.474 & 186.73 & 0.158 \\
100 & 3.69 & 190.70 & 0.157 \\
120 & 4.79 & 198.65 & 0.2 \\
\hline
\end{tabular}

\section{Conclusions:}

Experiments have been carried out to investigate the effects of different factors on $\mathrm{AE}$ and oxygen transfer rate in a mechanical surface aerator, with the following results:

1. The standard aeration efficiency and overall coefficient of the oxygen transfer KLa are affected by the aerator's relative submersion depth in the water. The results specified that the SAE and oxygen mass transfer coefficient (Kla) were at their best when the submersion depth ratio was $\mathrm{h} / \mathrm{D}=0.175$.

2. The SAE, which assesses aerator performance based on the aerator's power usage. Despite the fact that the value of $\mathrm{KLa}$ is optimal in a few cases, the aeration efficiency declines considerably. This is due to the fact that the power usage for that particular setup has increased.

3. When the rotating speed increases the standard aeration efficiency increases respectively

\section{Acknowledgement}

The authors would like to express their thanks to Al-Mustansiriya Univ. (www.uomustansiriyah.edu.iq) and college of engineering, Environmental department Baghdad-Iraq for the tremendous support.

\section{Abbreviations}

$\mathrm{dc} / \mathrm{dt} \quad$ Oxygen transfer rate in the water

$\mathrm{C}_{\mathrm{s}}$

Saturated oxygen concentration [mg/l]

Oxygen concentration at time $\mathrm{t}=$ $0[\mathrm{mg} / \mathrm{l}]$

$\mathrm{C}_{\mathrm{sT}} \quad$ Saturated oxygen concentration at temperature $\mathrm{T}[\mathrm{mg} / \mathrm{l}]$

Concentration of the Oxygen at time $t$ $=\mathrm{t}[\mathrm{mg} / \mathrm{l}]$

Dissolved Oxygen [mg/l]

D Diameter of the Rotor [cm]

$\mathrm{h} \quad$ Depth of the Submersion [cm]

General mass transfer coefficient at $\mathrm{k}_{\mathrm{L}} \mathrm{a}_{\mathrm{T}}$ the temperature of the water $\mathrm{T}\left[\mathrm{hr}^{-1}\right]$

$\mathrm{K}_{1} \mathrm{O} \quad$ Overall rate of oxygen transfer $\left[\mathrm{hr}^{-1}\right]$

$\mathrm{K}_{\mathrm{L}} \mathrm{a}_{20} \quad$ Overall coefficient of mass transfer at $20^{\circ} \mathrm{C}$ and $1 \mathrm{~atm}\left[\mathrm{hr}^{-1}\right]$

P $\quad$ Motor Power [W]

SAE Standard Aeration efficiency at $20^{\circ} \mathrm{C}$ [Kg O$/ \mathrm{kWhr}$ ]

SOTR Standard Oxygen transfer rate at $20^{\circ} \mathrm{C}$ and $1 \mathrm{~atm}\left[\mathrm{Kg} \mathrm{O}_{2} / \mathrm{m}^{3} . \mathrm{hr}\right]$

$\mathrm{T} \quad$ Time[min]

$\mathrm{T} \quad$ Water temperature for the test $\left[{ }^{\circ} \mathrm{C}\right]$

$\operatorname{Tr} \quad$ Reference temperature $\left(20^{\circ} \mathrm{C}\right)\left[{ }^{\circ} \mathrm{C}\right]$

$\mathrm{V} \quad$ Water tank volume $\left[\mathrm{m}^{3}\right]$

\section{Conflict of Interest}

The authors confirm that the publication of this article causes no conflict of interest.

\section{References}

1. Metcalf, Eddy (2003), "Wastewater Engineering: Treatment, Disposal and 
Reuse" Fourth ed., McGraw Hill, New York.

2. A.S. Khare, K. Niranjan, (1999), "An experimental investigation into the effect of impeller design on gas hold-up in a highly viscous Newtonian liquid" Chem. Eng. Sci. 54 (8) 1093-1100.

3. A. Amanullah, L. Serrano-Carreon, B. Castro, E. Galindo, A.W. Nienow (1998), "The influence of impeller type in pilot scale Xanthan fermentations", Biotechnol. Bioeng. 57 (1) 95-108.

4. M. Cooke, P.J. Heggs (2005), "Advantages of the hollow (concave) turbine for multi-phase agitation under intense operating conditions", Chem. Eng. Sci. 60 (20) 5529-5543.

5. Z.D. Chen, J.J. Chen (1999), "Comparison of mass transfer performance for various single and twin impellers", Chem. Eng. Res Des 77 (2) 104-109.

6. F. Saito, A.W. Nienow, S. Chatwin, I.T. Moore (1992), "Power, gas dispersion and homogenization characteristics of SCABASRGT and Rushton turbine impellers", J. Chem. Eng. Japan 25 281287.

7. B. Cancino (2004), "Design of high efficiency surface aerators Part2. Rating of surface aerator rotors", Aquacultural Eng. Elsevier. 3183-98.

8. B. Cancino, B. Roth, M. Reuß (2004), "Design of high efficiency surface aerators Part 1. Development of new rotors for surface aerators", Aquacultural Eng. Elsevier. Vol. (31) 99-115.

9. S.B. Thakre, B.L. Bhuyar, S.J. Deshmukh (2008), "Effect of different configurations of mechanical aerators on oxygen transfer and aeration efficiency with respect to power consumption", World Academy Sci. Eng. Technol. 14 442-450.

10. B.L. Bhuyar, S.B. Thakre, N.W. Ingole (2009), "Design characteristics of Curved Blade Aerator w.r.t. aeration efficiency and overall oxygen transfer coefficient and comparison with CFD modeling", Int. J. Eng. Sci. Technol. Vol. 1 1-15.

11. T.T. Devi, B. Malsur, B. Kumar (2011), "Stirred tank with arrowhead impellerinfluence of submergence depth on power consumption”, Chem. Eng. Res. Bull. 15 45-47.

12. B. Molna' r, A. Egedy, T. Varga (2014), "Analysis of mixing efficiency of Rushton turbines based on CFD models", Periodica Polytechnica Chem. Eng. 58 (2) 93-102.

13. A. Mohammadpour, M.A. AkhvanBehabadi, M. Nosrati, M. Ebrahimzadeh, A.R. Majdinasab (2015), "Evaluation and optimization of efficiency and mixing time in a surface aeration tank”, Int. J. Chem. Eng. Applicat. 6 (3) 160-164.

14. Roy, Supha Manash, Chanchal Kumar Mukherjee, and Bimal Chandra MAL, (2018). "Design characteristics of submersible aerator." Turkish Journal of Fisheries and Aquatic Sciences 18.9: 1017-1023.

15. Adel, M., Shaalan, M. R., Kamal, R. M., \& El Monayeri, D. S. (2019). “ $A$ comparative study of impeller aerators configurations". Alexandria Engineering Journal, 58(4), 1431-1438.

16. C. Boyd (1986), "A method for testing aerators for fish tanks, Prog. Fish Cult. 48 68-70.

17. Boyd, C. E., \& Watten, B. J. (1989). "Aeration systems in Aquacultural".

18. Pöpel, H. J. (1984)," Entwicklungstendenzen der Belüftung beim Belebungsverfahren. Wasser und Boden”, 36(5), 206-213

19. Wagner, M. (1997). "Sauerstoffeintrag und Sauerstoffertrag von Belüftungssystemen und deren Bestimmung mit modernen 
Messmethoden”. Verein zur Forderung des Instituts fur Wasserversorgung, Abwasserbeseitgung und Raumplanung der Technischen Hochschule Darmstadt.

20. ASCE (American Society of Civil Engineers) (2006), "Standard, Measurement of oxygen transfer in clean water, ASCE/EWRI 2-06.

21. J.R. Stukenberg, V.N. Wahbeh, R.E. McKinney, (1977), "Experiences in Evaluating and specifying aeration equipment," J. WPCF 66-82.

22. Treybal, R. E., \& García Rodríguez, A. (1988). "Operaciones de transferencia de masa".

23. Arceivala, Sorab Jal. (1981), "Wastewater treatment and disposal: engineering and ecology in pollution control". 